\title{
Evaluation of Cold Hardiness in Seven Iranian Commercial Pomegranate (Punica granatum L.) Cultivars
}

\author{
Ali Akbar Ghasemi Soloklui and Ahmad Ershadi ${ }^{1}$ \\ Department of Horticultural Sciences, Faculty of Agriculture, Bu-Ali Sina \\ University, Modares Square, Azadegan Boulevard, Hamedan, Iran
}

\section{Esmaeil Fallahi \\ Department of Plant, Soil, and Entomological Sciences, University of Idaho, Parma, ID 83660}

Additional index words. carbohydrate, cold hardiness, electrolyte leakage, pomegranate, proline, tetrazolium stain test

\begin{abstract}
Freezing injury is one of the most important limiting factors in commercial pomegranate production. The objectives of this study were to compare cold hardiness of seven Iranian pomegranate cultivars at three stages: November, January, and March, and to investigate the relationship between freezing tolerance and soluble carbohydrate and proline changes of shoots during acclimation and deacclimation. $\mathbf{L T}_{50}$ values, estimated by both electrolyte leakage measurement (EL LT $\mathbf{T}_{50}$ ) and tetrazolium stain test (TST LT $_{50}$ ), allowed us to discriminate between the cultivars in terms of freezing tolerance. Acclimation and deacclimation did not occur simultaneously in different cultivars, having a key role in cold tolerance of cultivars, especially in fall and late winter. Post Sefid Bafgh cultivar showed high cold tolerance early in fall, but it was susceptible to cold during winter. 'Naderi', 'Yusef Khani', 'Malas Saveh', and 'Robab Neyriz' had the highest midwinter cold hardiness; 'Mahabadi' showed an intermediate hardiness, whereas 'Post Sefid Bafgh' and 'Shishe Kap' were found to be cold-susceptible in this period. Freezing tolerance estimated by TST corresponded to those measured by the EL method in all cultivars, but in November and January, higher variation in freezing tolerance was observed among the cultivars through TST compared with EL measurement. However, LT $_{50}$ values, estimated by EL measurement, were lower than those estimated through TST in November and March. Soluble carbohydrate concentrations of stem samples increased during cold acclimation from November to January; then it decreased in March. Proline had a narrow range of variation among the cultivars in November, but an increase in the amount of proline was observed during the period of hardening. In general, stronger correlations were observed between $L T_{50}$ values and the amounts of soluble carbohydrates compared with proline, particularly from fall to midwinter.
\end{abstract}

Pomegranate (Punica granatum L.) is native from Iran to the Himalayas in northern India (Nemati et al., 2012), grown widely in Iran, India, Spain, Afghanistan, Pakistan, Turkey, and the United States (Elyatem and Kader, 1984; Sarkhosh et al., 2009). Iran has an annual production of $600,000 \mathrm{t}$ (Anonymous, 2008) and is vastly rich in genetic diversity of pomegranate. Yazd and Saveh are leading pomegranate-producing regions in Iran with germplasm collections being over 700 cultivars and accessions. Pomegranate has considerable soil and climatic adaptations and withstands frosty conditions but will not survive long below $-15{ }^{\circ} \mathrm{C}$. Pomegranates are mostly grown in the margins of deserts in central and northeastern Iran. These regions have long and hot summers, but the winter temperatures may plunge down to $-20{ }^{\circ} \mathrm{C}$ or

Received for publication 21 Feb. 2012. Accepted for publication 28 Sept. 2012

${ }^{1}$ To whom reprint requests should be addressed; e-mail Ershadi@basu.ac.ir. even lower, causing serious damage to pomegranate trees. Severe winter frost in 2007, when temperature reached $-21{ }^{\circ} \mathrm{C}$ for three consecutive days, destroyed at least 8000 ha of pomegranate orchards in Saveh, the second pomegranate-producing region in Iran, and had a serious adverse economic impact on growers.

Some biochemical changes such as increasing the amounts of total carbohydrates (Morin et al., 2007), proline (Lalk and Dorfflung, 1985), and proteins (Guy, 1990) occur during acclimation in plants. Carbohydrates may play an important role in osmotic adjustment contributing to avoidance of intracellular freezing. In addition to carbohydrates, plants accumulate proline during stresses such as low temperature, drought, and high salinity (Hare et al., 1999), inducing osmotic adjustment and water potential decline and allowing plants to tolerate dehydrative stresses (Delauney and Verma, 1993). Little information is available on the cold tolerance of pomegranate cultivars based on field observations after natural frosts in Iran.
There is a high risk of frost in central and northeastern parts of Iran, occurring almost every 10 years. Therefore, the objectives of this study were: 1) to determine cold hardiness of seven commercial Iranian pomegranate cultivars in different stages of the hardening cycle, from fall through winter; and 2) to study changes in carbohydrates and proline contents during acclimation and deacclimation as well as their relationships with freezing tolerance.

\section{Materials and Methods}

Plant material. Seven pomegranate cultivars including 'Mahabadi', 'Malas Saveh', 'Naderi', 'Post Sefid Bafgh', 'Robab Neyriz', 'Shishe Kap', and 'Yusef Khani' were used in this study. 'Malas Saveh' and 'Yusef Khani' are cultivars commercially grown in Saveh, Markazi province. 'Naderi' and 'Mahabadi' are leading cultivars of Naein and Ardestan, Isfahan province. 'Post Sefid Bafgh' and 'Shishe Kap' are from Bafgh, Yazd province, and Bajestan, Khorasan province, respectively. These provinces are located in the vicinity of Iran's central desert. However, Naein, Neyriz, and Saveh have relatively harsh climates with occasional severe frosts during winter, but Bafgh and Bajestan have mild winters.

One-year-old shoots $(30 \mathrm{~cm}$ in length) from five-year old trees (three shoots per cultivar and replicate) were collected at three stages: November, January, and March, from Saveh Pomegranate Research Center, Iran (lat. $34^{\circ} 59^{\prime} \mathrm{N}$, long. $50^{\circ} 11^{\prime} \mathrm{E}$, alt. $1145 \mathrm{~m}$ ). Samples were wrapped in wet paper, sealed in plastic bags, and kept at $5{ }^{\circ} \mathrm{C}$ during transportation from the field to the laboratory.

Freezing procedure. Shoots were washed with deionized water and cut into $1-\mathrm{cm}$ long segments; five pieces were placed into $50-\mathrm{mL}$ plastic tubes per replicate. The experiment was conducted using a completely randomized design with three replicates. One milliliter of deionized water was added to each sample for immediate ice formation. Tubes were transferred to a freezing chamber (Kimia Rahavard, Tehran, Iran) to expose them to low temperatures. Starting temperature was $5^{\circ} \mathrm{C}$ and cooling rate was $2^{\circ} \mathrm{C} \cdot \mathrm{h}^{-1}$. Treatment temperatures at three acclimation stages were:

Acclimation stage one (27 Nov. 2010): -6 , $-9,-12,-15,-18^{\circ} \mathrm{C}$

Acclimation stage two (30 Jan. 2010): -12, $-15,-18,-21,-24{ }^{\circ} \mathrm{C}$.

Acclimation stage three (12 Mar. 2011): $-12,-15,-18,-21^{\circ} \mathrm{C}$.

Samples were kept at final temperature for $1 \mathrm{~h}$ and then removed from the freezing chamber.

Electrolyte leakage. Twenty milliliters of deionized water was added to each tube, shaken for $1 \mathrm{~h}(250 \mathrm{rpm})$ at $23{ }^{\circ} \mathrm{C}$, and kept at room temperature for $24 \mathrm{~h}$ before the first electrical conductivity (EC1) measurement 
was carried out. Samples were then autoclaved at $120^{\circ} \mathrm{C}$ for $20 \mathrm{~min}$ to allow maximum leakage of ions, cooled at room temperature for $2 \mathrm{~h}$, then EC (EC2) was measured again. Relative electrolyte leakage (REL) was calculated using the formula: $\mathrm{REL}=(\mathrm{EC} 1 / \mathrm{EC} 2) \times 100$.

Tetrazolium stain test. Freezing treatments were similar to those used in EL tests. After freezing treatments, stem samples (five 1-cm long pieces per replicate) were removed from the freezing chamber and placed on ice for slow thawing, and subsequently $5 \mathrm{~mL}$ from a solution of $1 \%$ 2,3,5-triphenyle tetrazolium chloride was added to each tube. Samples were then kept for $24 \mathrm{~h}$ in the dark at room temperature and dead tissues monitored by a stereomicroscope (Leica MS5, Wetzlar, Germany). Samples that did not turn red in phloem were considered dead. The intensity of staining varied within the various cultivars, and samples were considered stained across a variety of red hues. Mortality percentage was calculated by dividing the number of dead stem samples by the total number of samples.

Cold hardiness was expressed as $\mathrm{LT}_{50}$ (lethal temperature at which $50 \%$ of the total ion leakage occurs; or, in the case of TST, the lethal temperature at which $50 \%$ of the tissues are dead) by fitting response curves with the following logistic sigmoid function (Fiorino and Mancuso, 2000):

$$
\mathrm{R}=\frac{\mathrm{a}}{1+\mathrm{e}^{\mathrm{b}(\mathrm{x}-\mathrm{c})}}+d
$$

where $\mathrm{R}=\mathrm{REL}$ or mortality percentage, based on $\mathrm{LT}_{50}$ estimation method used; $\mathrm{x}=$ treatment temperature; $b=$ slope of the function at the inflection point $\mathrm{c}$; and a and $\mathrm{d}$ determine the upper and lower asymptotes of the function, respectively.

Soluble carbohydrates. Soluble carbohydrates were determined based on the anthrone method (Yemm and Willis, 1954). Stem samples were powdered using liquid nitrogen. Soluble carbohydrates were extracted three times from $1 \mathrm{~g}$ of ground tissue with $5 \mathrm{~mL}$ of $80 \%$ ethanol and centrifuged for $15 \mathrm{~min}$ at $1500 g_{n}$. One milliliter of $0.2 \%$ anthrone reagent $(2 \mathrm{~g}$ anthrone in $1 \mathrm{~L}$ of $72 \%$ sulfuric acid) was added to $100 \mu \mathrm{L}$ of the ethanolic extract. The reaction mixture was heated in a boiling water bath for $10 \mathrm{~min}$ and then rapidly cooled on ice. Absorbance was spectrophotometrically measured at $620 \mathrm{~nm}$. Soluble carbohydrate concentration was finally calculated through a calibration curve and expressed as milligrams soluble carbohydrates/gram dry weight.

Proline. Free proline concentration was determined as described by Bates et al. (1973). Stem samples were ground in liquid nitrogen and $0.5 \mathrm{~g}$ of ground tissue homogenized in $10 \mathrm{~mL}$ of $3 \%(\mathrm{w} / \mathrm{v})$ aqueous sulfosalicylic acid. Homogenate was then filtered through a Whatman No. 1 filter paper. Two milliliters of filtered extract was taken for the analysis, to which $2 \mathrm{~mL}$ ninhydrin and $2 \mathrm{~mL}$ glacial acetic acid were added. The reaction mixture was incubated in a boiling water bath for $1 \mathrm{~h}$ and the reaction was finished in an ice bath.
Four milliliters of toluene was added to the mixture and the organic phase was extracted. Absorbance of the extract was read at $520 \mathrm{~nm}$ using an ultraviolet-visible spectrophotometer (Bel Engineering Srl, Monza, Italy), whereas toluene was used as a blank. Proline concentration was finally calculated through a calibration curve and expressed as micromole proline/gram fresh weight.

Statistical analyses. Differences among cultivars in EL $\mathrm{LT}_{50}$, TST LT $\mathrm{LT}_{50}$, soluble carbohydrates, and proline concentrations at each acclimation stage were analyzed using a oneway analysis of variance (PROC GLM; SAS Institute, 2003). Means were separated using Duncan's multiple range tests $(P \leq 0.05)$. Correlation analysis among soluble carbohydrates, proline concentrations, and $\mathrm{LT}_{50}$ values, estimated by TST and EL measurement, were performed using Pearson's correlation coefficient (PROC CORR).

\section{Results}

Cold hardiness as estimated by electrolyte leakage. As shown in Table1, $\mathrm{EL} \mathrm{LT}_{50}$ varied significantly among cultivars at each acclimation stage. Based on EL $\mathrm{LT}_{50}$ values, in November, 'Post Sefid Bafgh' and 'Naderi' showed the highest freezing tolerance, whereas no difference was noticed among the other cultivars. From November (early hardening) to January (full hardening), cold hardiness of all cultivars considerably increased. However, cultivars did not show similar acclimation rates; for example, $\mathrm{EL} \mathrm{LT}_{50}$ values in 'Post Sefid Bafgh' and 'Yusef Khani' decreased $\approx 4.7$ and $8.1{ }^{\circ} \mathrm{C}$, respectively, during the hardening period. The most coldtolerant cultivars that withstood $-22{ }^{\circ} \mathrm{C}$ or even lower temperatures in January were 'Naderi', 'Yusef Khani', and 'Malas Saveh', whereas the least hardy cultivars, Post Sefid Bafgh and Shishe Kap, reached at 50\% mortality at -20 and $-20.5{ }^{\circ} \mathrm{C}$, respectively.

A dramatic difference in freezing tolerance was observed among cultivars in dehardening period in March. In 'Mahabadi' and 'Post Sefid Bafgh', EL LT ${ }_{50}$ occurred at -12.1 and $-13.8{ }^{\circ} \mathrm{C}$, respectively, but 'Yusef Khani' and 'Naderi' indicated 50\% mortality at -19 and $-18.4^{\circ} \mathrm{C}$, respectively. 'Malas Saveh', 'Robab Neyriz', and 'Shishe Kap' showed intermediate hardiness.

Cold hardiness as estimated by tetrazolium stain test. Results of TST $\mathrm{LT}_{50}$ are presented in Table 2. 'Post Sefid Bafgh', the most freezing-tolerant cultivar, in November reached $\mathrm{LT}_{50}$ at $-13.8{ }^{\circ} \mathrm{C}$, whereas in the remaining cultivars, $\mathrm{LT}_{50}$ occurred at -7.7 to $-9.2^{\circ} \mathrm{C}$. Cold hardiness of 'Post Sefid Bafgh' increased slightly in January, whereas other cultivars showed considerable hardening enhancement. According to the TST $\mathrm{LT}_{50}$ estimations in January, cultivars could be divided into three groups: 1) freezing-tolerant cultivars including 'Naderi', 'Malas Saveh', 'Yusef Khani', and 'Robab Neyriz'; 2) freezing-susceptible cultivars consisting of 'Shishe Kap' and 'Post Sefid Bafgh'; and 3) 'Mahabadi' with intermediate hardiness. Cold hardiness of all cultivars reduced considerably in March, and they showed a similar ranking in freezing tolerance, as seen in January, except for 'Mahabadi' as the least hardy cultivar in this stage.

Table $1 . \mathrm{LT}_{50}$ values \pm SES $(\mathrm{n}=3)$, estimated by stem electrolyte leakage measurement in seven Iranian commercial pomegranate cultivars in November, January, and March.

\begin{tabular}{lccc}
\hline & \multicolumn{3}{c}{$\mathrm{LT}_{50}\left({ }^{\circ} \mathrm{C}\right)$} \\
\cline { 2 - 4 } Cultivar & November & January & March \\
\hline Mahabadi & $-13.5 \pm 0.2 \mathrm{c}^{\mathrm{z}}$ & $-21.0 \pm 0.1 \mathrm{bc}$ & $-12.1 \pm 0.1 \mathrm{e}$ \\
Malas Saveh & $-14.3 \pm 0.2 \mathrm{bc}$ & $-22.1 \pm 0.1 \mathrm{a}$ & $-16.8 \pm 0.1 \mathrm{~b}$ \\
Naderi & $-15.1 \pm 0.0 \mathrm{ab}$ & $-22.2 \pm 0.1 \mathrm{a}$ & $-18.4 \pm 0.1 \mathrm{a}$ \\
Post Sefid Bafgh & $-15.3 \pm 0.1 \mathrm{a}$ & $-20.0 \pm 0.6 \mathrm{~d}$ & $-13.8 \pm 0.1 \mathrm{~d}$ \\
Robab Neyriz & $-14.3 \pm 0.2 \mathrm{bc}$ & $-21.5 \pm 0.1 \mathrm{ab}$ & $-15.0 \pm 0.0 \mathrm{c}$ \\
Shishe Kap & $-13.9 \pm 0.0 \mathrm{c}$ & $-20.5 \pm 0.1 \mathrm{~cd}$ & $-15.0 \pm 0.2 \mathrm{c}$ \\
Yusef Khani & $-14.2 \pm 0.1 \mathrm{bc}$ & $-22.3 \pm 0.1 \mathrm{a}$ & $-19.0 \pm 0.1 \mathrm{a}$ \\
Overall mean & $14.4 \pm 0.2$ & $21.4 \pm 0.2$ & $15.7 \pm 0.5$ \\
$P$ value & $\leq 0.001$ & $\leq 0.001$ & $\leq 0.001$ \\
CV (\%) & 12.0 & 2.0 & 2.4 \\
\hline
\end{tabular}

${ }^{\mathrm{z}}$ Similar letters in each column indicate nonsignificant differences among cultivars at $P \leq 0.05$.

Table $2 . \mathrm{LT}_{50}$ values \pm SES $(\mathrm{n}=3)$, estimated by tetrazolium stain test in seven Iranian commercial pomegranate cultivars in November, January, and March.

\begin{tabular}{lccc}
\hline & \multicolumn{3}{c}{$\mathrm{LT}_{50}\left({ }^{\circ} \mathrm{C}\right)$} \\
\cline { 2 - 4 } Cultivar & November & January & March \\
\hline Mahabadi & $-8.4 \pm 0.4 \mathrm{~b}^{\mathrm{z}}$ & $-18.6 \pm 0.4 \mathrm{ab}$ & $-10.7 \pm 0.3 \mathrm{c}$ \\
Malas Saveh & $-8.0 \pm 0.6 \mathrm{~b}$ & $-23.1 \pm 0.9 \mathrm{a}$ & $-15.8 \pm 0.4 \mathrm{a}$ \\
Naderi & $-9.2 \pm 0.1 \mathrm{~b}$ & $-23.0 \pm 0.6 \mathrm{a}$ & $-15.4 \pm 0.2 \mathrm{a}$ \\
Post Sefid Bafgh & $-13.8 \pm 0.2 \mathrm{a}$ & $-16.9 \pm 0.1 \mathrm{~b}$ & $-11.2 \pm 0.3 \mathrm{c}$ \\
Robab Neyriz & $-7.7 \pm 0.2 \mathrm{~b}$ & $-23.9 \pm 0.4 \mathrm{a}$ & $-14.4 \pm 0.1 \mathrm{ab}$ \\
Shishe Kap & $-7.9 \pm 0.6 \mathrm{~b}$ & $-16.7 \pm 0.3 \mathrm{~b}$ & $-12.5 \pm 0.4 \mathrm{bc}$ \\
Yusef Khani & $-8.6 \pm 0.2 \mathrm{~b}$ & $-23.0 \pm 0.8 \mathrm{a}$ & $-16.5 \pm 0.4 \mathrm{a}$ \\
Overall mean & $9.1 \pm 0.5$ & $20.6 \pm 0.8$ & $13.8 \pm 0.5$ \\
$P$ value & $\leq 0.001$ & $\leq 0.018$ & $\leq 0.001$ \\
CV (\%) & 12.0 & 13.0 & 8.7 \\
\hline
\end{tabular}

${ }^{\mathrm{z}}$ Similar letters in each column indicate nonsignificant differences among cultivars at $P \leq 0.05$. 
There was an overall agreement between results obtained from two methods. TST $\mathrm{LT}_{50}$ values were well correlated with EL $\mathrm{LT}_{50}$ values in November $(r=0.64, P \leq 0.001$, $\mathrm{n}=21)$, January $(r=0.70, P \leq 0.001, \mathrm{n}=21)$ and March $(r=0.83, P \leq 0.001, \mathrm{n}=21)$. However, variations in freezing tolerance among cultivars, in November and January, evaluated by TST $\mathrm{LT}_{50}$, were higher than variations estimated through EL $\mathrm{LT}_{50}$ measurement. Moreover, cold hardiness estimated by EL measurement was higher than that estimated through TST in all three stages (Tables 1 and 2).

Soluble carbohydrates. As shown in Figure 1, concentrations of soluble carbohydrates increased during cold acclimation from November to January and then decreased in March; overall means were 43, 118 , and $61 \mathrm{mg} \cdot \mathrm{g}^{-1}$ dry weight (DW), respectively. In November, significant differences $(P \leq 0.01)$ existed in soluble carbohydrate concentrations among cultivars. The maximum amount was related to 'Post Sefid Bafgh', whereas the least rates were observed in 'Malas Saveh', 'Robab Neyriz', and 'Mahabadi'. From November to January, concentrations of soluble carbohydrates increased by two to four times in all cultivars except for 'Post Sefid Bafgh'. At this stage, maximum amounts 160,160 , and $122 \mathrm{mg} \cdot \mathrm{g}^{-1} \mathrm{DW}$ were detected in 'Naderi', 'Malas Saveh', and 'Yusef Khani', respectively, whereas the other cultivars were not significantly different in soluble carbohydrate concentration. Soluble carbohydrates were considerably dropped in March and no difference was observed among cultivars at this stage. A high correlation between both EL $\mathrm{LT}_{50}$ and TST $\mathrm{LT}_{50}$ and soluble carbohydrates was found in November and January. However, there was no relationship between EL $\mathrm{LT}_{50}$ and TST $\mathrm{LT}_{50}$ and soluble carbohydrate concentrations in March (Table 3).

Proline. Proline concentrations had a narrow range of variation among cultivars in November from 0.45 to $0.67 \mu \mathrm{mol} \cdot \mathrm{g}^{-1}$ fresh weight (Fig. 2). An increase in proline was observed during hardening, especially for 'Naderi' and 'Yusef Khani'. Proline accumulated more in March compared with the other sampling dates in all cultivars except for 'Naderi' and 'Post Sefid Bafgh'. EL LT ${ }_{50}$ was correlated with the amount of stem proline in January, whereas no correlation was found between proline concentration and EL $\mathrm{LT}_{50}$ in November and March. There were correlations between TST $\mathrm{LT}_{50}$ and proline in November and January (Table 3).

\section{Discussion}

EL measurement and TST after controlled freezing allowed us to discriminate among pomegranate cultivars regarding their freezing tolerance. Freezing tolerance of the cultivars studied significantly differed at each acclimation stage and they did not acclimate and deacclimate simultaneously. According to $\mathrm{TST} \mathrm{LT}_{50}$ and EL $\mathrm{LT}_{50}$ estimations, cold

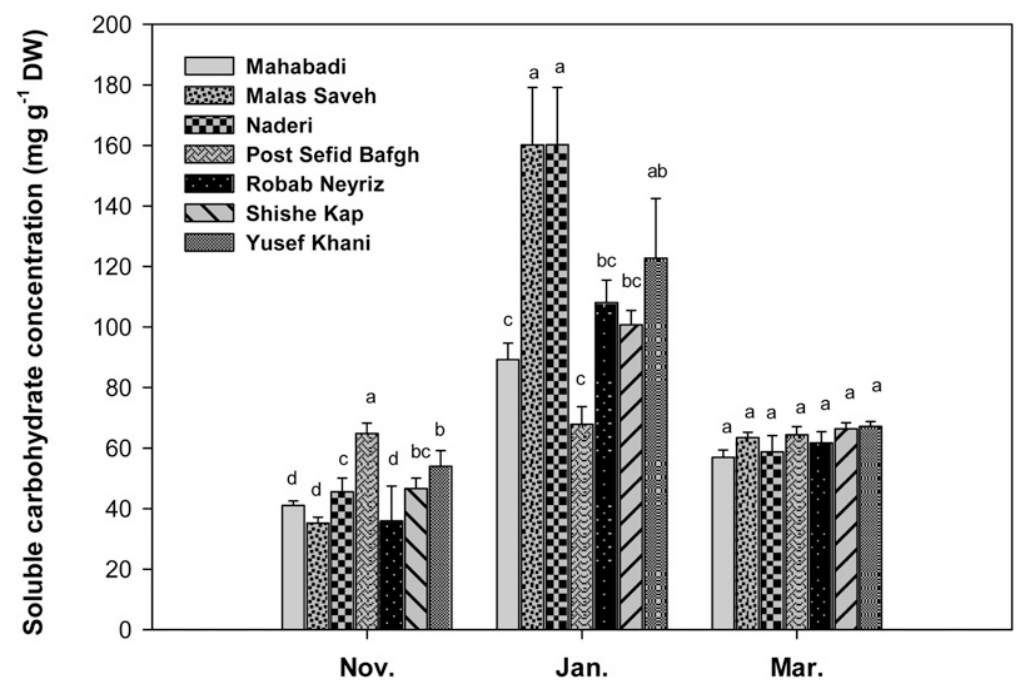

Fig. 1. Changes in soluble carbohydrate concentrations in stem of seven Iranian commercial pomegranate cultivars over a period of four months. Values are means $\pm \mathrm{SE}$ of three replicates. Similar letters at the top of columns indicate nonsignificant differences among cultivars at each acclimation stage at $P \leq 0.05$.

Table 3. Pearson correlation coefficients among EL LT $50, \mathrm{TST} \mathrm{LT}_{50}$, and the concentrations of soluble carbohydrates and proline in stems of seven Iranian pomegranate cultivars in three stages of November, January, and March. ${ }^{\mathrm{z}}$

\begin{tabular}{|c|c|c|c|c|}
\hline Variables & November & January & March & All three stages \\
\hline & \multicolumn{4}{|c|}{ Soluble carbohydrates } \\
\hline $\mathrm{EL} \mathrm{LT}_{50}$ & $-0.48 *$ & $-0.80 * * *$ & NS & $-0.80 * * *$ \\
\hline \multirow[t]{2}{*}{$\mathrm{TST} \mathrm{LT}_{50}$} & $-0.72 * * *$ & $-0.65^{* * *}$ & NS & $-0.84 * * *$ \\
\hline & \multicolumn{4}{|c|}{ Proline } \\
\hline $\mathrm{EL} \mathrm{LT}_{50}$ & NS & $-0.59 * *$ & NS & $-0.30 *$ \\
\hline TST LT $_{50}$ & $-0.59 * *$ & $-0.65 * * *$ & NS & $-0.47 * *$ \\
\hline
\end{tabular}

${ }^{\mathrm{z}}$ Number of observations per each stage and all three stages together were 21 and 63, respectively. NS, $*, * *, * * *$ Nonsignificant or significant at $P \leq 0.05,0.01$, or 0.001 , respectively.

$\mathrm{EL}=$ electrolyte leakage; TST $=$ tetrazolium stain test.

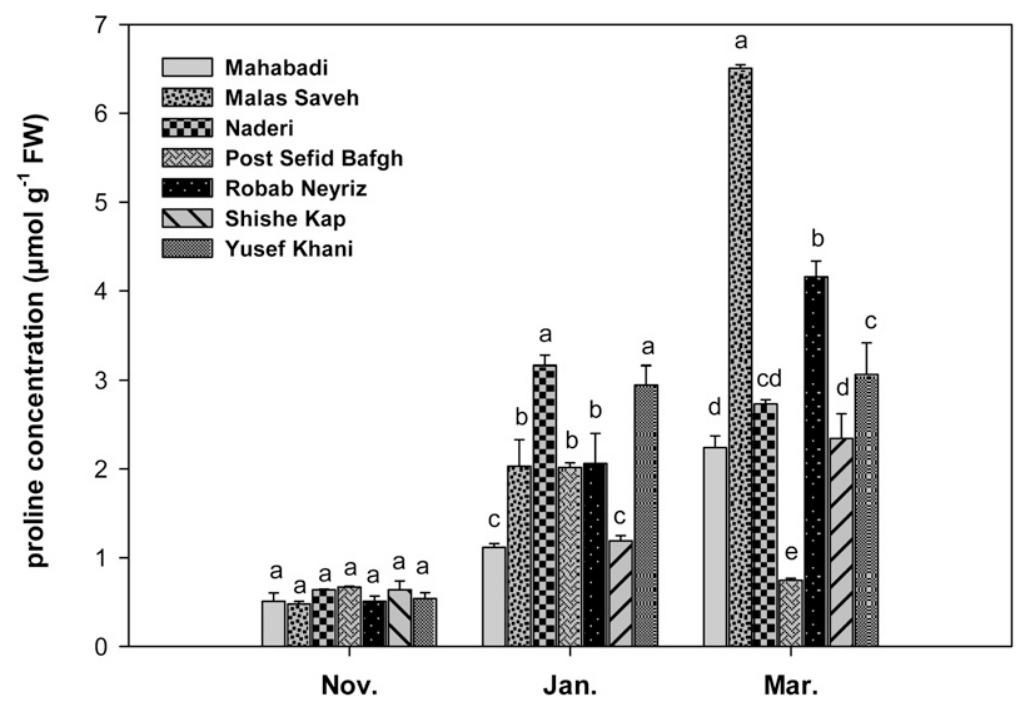

Fig. 2. Changes in proline concentrations in stem of seven Iranian commercial pomegranate cultivars. Values are means \pm SE of three replicates. Similar letters at the top of columns indicate nonsignificant differences among cultivars at each acclimation stage at $P \leq 0.05$.

hardiness developed earlier in 'Post Sefid Bafgh' than other cultivars. High freezing tolerance of 'Post Sefid Bafgh' seen in November, is apparently a consequence of early leaf abscission and higher acclimation rate in this cultivar. However, this cultivar showed the least cold hardiness enhancement from November to January compared with other 
cultivars. Although EL $\mathrm{LT}_{50}$ and TST $\mathrm{LT}_{50}$ had a high correlation in November, $\mathrm{LT}_{50}$ values, estimated by two methods, did not occur at similar temperatures. EL $\mathrm{LT}_{50}$ is associated with erratic function or total dysfunction of plasma membranes after freezing stress but TST LT $\mathrm{LT}_{50}$ is related to the ability of tissues to respire after exposure to cold stress. Our results showed that the amounts of cold hardiness estimated by the EL method were higher than those evaluated in terms of TST in November and March. The difference between freezing tolerance of the most and least tolerant cultivars in November, 'Post Sefid Bafgh', and 'Mahabadi', estimated by EL measurement and TST were 1.8 and $6{ }^{\circ} \mathrm{C}$, respectively.

Previous studies on pecan (Carya illinoinensis Wangenh.) showed that TST $\mathrm{LT}_{50}$, apart from midwinter, occurred at higher temperatures compared with EL LT ${ }_{50}$ (Omar Bafeel, 2005) and low-temperature exotherm (Ketchie and Kammereck, 1987). However, similar $\mathrm{LT}_{50}$ values, estimated by EL measurement and TST of phloem tissues, were reported for satsuma mandarin (Citrus unshiu Marc.) (Nesbitt et al., 2002).

Although Omar Bafeel (2005) suggested that TST was not as reliable as EL measurement in establishing lethal temperatures in pecan, several researchers considered TST as an accurate and ideal method for determining cold injury in woody plants such as apple (Malus domestica Borkh.) (Matta and Kawatin, 1994) and 'Satsuma' mandarin (Nesbitt et al., 2002). An extensive comparison of various methods to assess freezing injuries in pomegranate should be considered in the future. Comparing the results of EL measurement and TST with visual rating of damage after a freezing test may reveal the reliability of each method for pomegranate.

Based on TST LT 50 and EL LT 50 values, 'Shishe Kap' and 'Post Sefid Bafgh' were the least cold-tolerant cultivars in January. Our results were entirely in agreement with the field results obtained during severe winter frost in 2007, when pomegranate orchards of 'Shishe Kap', one of the four Iranian leading pomegranate cultivars, were completely destroyed in several regions of Khorasan province.

Presumably considerable variation in freezing tolerance observed between the cultivars in March is mainly the result of their differences in deacclimation rate. Based on the EL $\mathrm{LT}_{50}$ values, 'Mahabadi' was the least tolerant and 'Yusef Khani' along with 'Naderi' were the most tolerant cultivars to late winter frosts.

When three stages were pooled, correlation coefficients between cold hardiness and soluble carbohydrates were highly significant, the strongest correlations observed in January. Moreover, the maximum concentrations of soluble carbohydrates and maximum cold hardiness were observed simultaneously in January. These results conform to studies that have been done on walnut (Juglans regia L.) (Améglio et al., 2004) and pedunculate oak (Quercus rubra L.) (Thomas et al., 2004).
Soluble carbohydrates play an important role in osmotic adjustment of cells, preventing intracellular freezing. However, a few research groups reported no significant relationship between carbohydrate concentrations and freezing tolerance in woody plants (Cox and Stushnoff, 2001; Pagter et al., 2008). Significant differences in cold hardiness were observed between cultivars in March, although there was no difference in soluble carbohydrate levels in this stage. Carbohydrates are either allocated to processes such as cell grow or converted to starch during deacclimation (Morin et al., 2007). Palonen (1999) stated that changes in both cold hardiness and carbohydrates probably are induced by weather changes, and coincidence between high concentration of carbohydrates and cold hardiness does not necessarily prove a causal relationship between them. However, there are numerous reports that provide different results regarding the positive relationship between winterhardiness and carbohydrates reserves (Palonen et al., 2000; Webster and Ebdon, 2005).

There was not a strong relationship between cold hardiness and proline content in stems compared with soluble carbohydrates. High proline content did not really indicate high cold hardiness, because proline levels were still high after deacclimation in March. Proline concentration in higher plants is associated with serious abiotic stress such as chilling stress (Taylor, 1996). Proline accumulates slowly in plants after onset of stress and typically after acquisition of frost tolerance (Koster and Lynch, 1992; Wanner and Junttila, 1999). Proline protects cell membranes through hydrophobic interactions, but it is less efficient under severe cold stress (Santarius, 1992; Van Swaaij et al., 1985).

In conclusion, there was a relationship between the natural habitat of cultivars and their cold hardiness. Although all cultivars studied are grown in the vicinity of central desert of Iran, cultivars grown in the regions with a harsh winter climate of Naein, Isfahan province ('Naderi'); Saveh, Markazi province ('Yusef Khani' and 'Malas Saveh'); and Neyriz, Fars province ('Robab Neyriz') had higher and longer cold hardiness. Cold-susceptible cultivars 'Post Sefid Bafgh' and 'Shishe Kap' are leading cultivars of Bajestan, Khorasan province, and Bafgh, Yazd province, respectively, regions with relatively mild winters. However, based on EL $\mathrm{LT}_{50}$ values, remarkable differences in freezing tolerance of cultivars were not found in midwinter. Soluble carbohydrates, especially from fall to midwinter, proved to be better indicators of cold hardiness compared with proline. This is the first report of accurate quantification of cold hardiness of the most important Iranian pomegranate cultivars, which may lead in sustainable fruit production and successful breeding programs in the future. Cultural practices (especially nutrition) may improve cold hardiness through their effects on carbohydrate reserves and are worthy of being considered in future research.

\section{Literature Cited}

Améglio, T., M. Decourteix, G. Alves, V. Valentin, S. Sakr, J.L. Julien, G. Petel, A. Guilliot, and A. Lacointe. 2004. Temperature effects on xylem sap osmolarity in walnut trees: Evidence for a vitalistic model of winter embolism repair. Tree Physiol. 24:785-793.

Anonymous, 2008. Iran statistical year book. Area under cultivation and production of selected perennial crops. Statistical Center of Iran Press.

Bates, L.S., R.P. Waldren, and I.D. Teare. 1973. Rapid determination of free proline for water stress studies. Plant Soil 39:205-207.

Cox, S.E. and C. Stushnoff. 2001. Temperaturerelated shifts in soluble carbohydrate content during dormancy and cold acclimation in $P O-$ pulus tremuloides. Can. J. For. Res. 31:730-737.

Delauney, A.J. and D.P.S. Verma. 1993. Proline biosynthesis and osmoregulation in plants. Plant J. 4:215-223.

Elyatem, S.M. and A. Kader. 1984. Post harvest physiology and storage behavior of pomegranate fruits. Sci. Hort. 24:287-298.

Fiorino, P. and S. Mancuso. 2000. Differential thermal analysis, supercooling and cell viability in organs of Olea europaea at subzero temperatures. Adv. Hort. Sci. 14:23-27.

Guy, C.L. 1990. Cold-acclimation and freezing stress: Tolerance role of protein metabolism. Annu. Rev. Plant Physiol. 41:187-223.

Hare, P.D., W.A. Cress, and J. Van Staden. 1999. Proline synthesis and degradation: A model system for elucidating stress-related signal transduction. J. Expt. Bot. 50:413-434.

Ketchie, P.O. and R. Kammereck. 1987. Seasonal variation of cold resistance in Mauls woody tissue as determined by differential thermal analysis and viability test. Can. J. Bot. 65: 2640-2645.

Koster, K.L. and D.V. Lynch. 1992. Solute accumulation and compartmentalization during the cold acclimation of Puma rye. Plant Physiol. 98:108-113

Lalk, I. and K. Dorfflung. 1985. Hardening, abscisic acid, proline and freezing resistance in two winter wheat varieties. Physiol. Plant. 63:287292.

Matta, F.B. and A.F. Kawatin. 1994. Cold acclimation and deacclimation of pecan trees. Gen. Tech. Rep. Soc. 104:127-130.

Morin, X., T. Ameglio, R. Ahas, C. Kurz-Besson, V. Lanta, F. Lebourgeois, F. Miglietta, and I. Chuine. 2007. Variation in cold hardiness and carbohydrate concentration from dormancy induction to bud burst among provenances of three European oak species. Tree Physiol. 27: 817-825.

Nemati, Z., A. Tehranifar, M. Farsi, A.M. Kakhki, H. Nemati, and M. Khayat. 2012. Evaluation of genetic diversity of Iranian pomegranate cultivars using fruit morphological characteristics and AFLP markers. Not. Bot. Hort. Agrobot. 40:261-268

Nesbitt, M.L., R.C. Ebel, D. Findley, B. Wilkins, F. Woods, and D. Himelrick. 2002. Assays to assess freeze injury of Satsuma mandarin. HortScience 37:871-877.

Omar Bafeel, S. 2005. Fatty acid composition and cold hardiness of pecan cultivars. PhD diss., Mississippi State University, MS.

Pagter, M., C.R. Jensen, K.K. Petersen, F. Liu, and R. Arora. 2008. Changes in carbohydrates, $\mathrm{ABA}$ and bark proteins during seasonal cold acclimation and deacclimation in Hydrangea species differing in cold hardiness. Physiol. Plant. 134:473-485.

Palonen, P. 1999. Relationship of seasonal changes in carbohydrates and cold hardiness in canes 
and buds of three red raspberry cultivars. J. Amer. Soc. Hort. Sci. 124:509-513.

Palonen, P., D. Buszard, and D. Donnelly. 2000. Changes in carbohydrates and freezing tolerance during cold acclimation of red raspberry cultivars grown in vitro and in vivo. Physiol. Plant. 110:393-401.

Santarius, K.A. 1992. Freezing of isolated thylakoid membranes in complex media. VIII. Differential cryoprotection by sucrose, proline and glycerol. Physiol. Plant. 84:87-93.

Sarkhosh, A., Z. Zamani, R. Fatahi, and H. Ranjbar. 2009. Evaluation of genetic diversity among Iranian soft-seed pomegranate accessions by fruit characteristics and RAPD markers. Sci. Hort. 121:313-319.

SAS Institute. 2003. SAS version 9.1. SAS Institute, Cary, NC.

Taylor, C.B. 1996. Proline and water deficit: Ups and downs. Plant Cell 8:1221-1224.

Thomas, F.M., G. Meyer, and M. Popp. 2004. Effects of defoliation on the frost hardiness and the concentrations of soluble sugars and cyclitols in the bark tissue of pedunculate oak (Quercus rubra L.). Ann. Sci. For. 61:455463.

Van Swaaij, A.C., E. Jacobsen, and W.J. Feenstra. 1985. Effect of cold hardening, wilting and exogenously applied proline on leaf proline content and frost tolerance of several genotypes of Solanum. Physiol. Plant. 64:230-236.

Wanner, L.A. and O. Junttila. 1999. Cold-induced freezing tolerance in Arabidopsis. Plant Physiol. 120:391-399.

Webster, D.E. and J.S. Ebdon. 2005. Effect of nitrogen and potassium fertilization on perennial ryegrass cold tolerance during deacclimation in late winter and early spring. HortScience 40:842-849.

Yemm, E.W. and A.J. Willis. 1954. The estimation of carbohydrates in plant extracts by anthrone. Biochem. J. 57:508-514. 